\title{
SARMITE TUBELE
}

Riga Teacher Training and Educational Management Academy University of Latvia, Faculty of Education, Psychology and Art, Latvia

\section{Prevention of Speech and Language Disorders in Preschool Children}

\begin{abstract}
Article "Prevention of Speech and Language Disorders in Preschool Children" is devoted to reveal content and directions of the work with preschool children in the so called group of risk. Speech and language pathologists are working with children in Latvia mostly starting at the age of 5, but sometimes time is lost and specific problems are present. There are specialists of early intervention but their activities are not obligatory and mostly they are available in private kindergartens or in developmental centres. It is necessary to speak about prevention because this issue is as a topic in many countries in Europe and in the whole world, but there are no many countries where it is determined by legal acts. Speech and language pathologists are speaking about three levels of prevention: primary, secondary and tertiary, where each level has its main goals and objectives. When speaking about preschool children at the age of three, mostly it is the primary prevention which should be organized and carried out.

There are statements about the categories of children which are included in the so called group of risk and what are duties of preschool teachers to help speech and language pathologist to think about children and to carry out some specific activities such as articulation exercises, breathing and blowing exercises, exercises to activate movements of fingers and tasks to promote phonological awareness. Physical impairments such as cleft lip, cleft palate and tongue-tie are not described in this context because in this case intensive speech therapy is needed.

The aim of the study is to give a theoretical framework of content and tasks of prevention of speech and language disorders in preschool children.

Methods include an analysis of theoretical literature.

Although many articulation errors are developmental in nature, some are related to phonological processing disorders. Children with these disorders are at a very high risk for later learning disabilities (problems in reading and writing) and therefore should be taken into account and treated as early as possible.
\end{abstract}

Key words: prevention, speech and language disorders, preschool children, group of risk, intervention.

\section{Introduction}

Children's speech development varies from individual to individual. However, there are typical stages that children go through in their speech and language 
development, when it is not so at some specific age, speech delay or impairment is suspected. Some mispronunciations are normal among preschool children but some features could be seen as indicators whether there should be concern for a child's articulation. In some cases articulation problems may indicate on a delay in muscle development or coordination needed for articulating speech sounds. Some delay in articulation may be as a result of chronic ear diseases, physical impairment or other conditions. Very serious problems occur when children have phonological processing disorders, we can see it on early stages of the development, but what can we do?

One of the possibilities is to think about prevention activities, therefore three stages of prevention are described and focus on the primary prevention is made. Although many articulation errors are developmental in nature, some are related to phonological processing disorders. Children with these disorders are at a very high risk for later learning disabilities (problems in reading and writing) and therefore should be taken into account and treated as early as possible, preferable starting at the age of three.

\section{Aim of the Study}

The aim of the study is to give a theoretical framework of content and tasks of prevention of speech and language disorders in preschool children.

\section{Motivation and Methods}

Materials and methods include an analysis of theoretical literature.

\section{Results}

In the preschool age the speech of child acquires new quality, there is a rapid growth in the vocabulary, and grammatical regularities of the language are intensively acquired. Already in the first years of the child in the speech of the child take place enormous changes: development of the voice responses, improvement of the imitation, understanding; the child uses its first words. In the second year continues the improvement of understanding and imitation, the active vocabulary increases fast; in the third year the vocabulary increases even more and vocabulary is specified, there is adequate use of grammatical forms and child is already using different syntax constructions (Сохин, 1979). Several authors consider (Фомичева, 1989; Rüke-Dravina, 1992) that in the age of five years the speech in its basics is already phonetically and grammatically developed - all sounds of native language are pronounced precisely, there is accumulated sufficient vocabulary, acquired basics of language grammatical constructions; the child has learnt skills of dialogue, there are also certain skills in the formation of the monologue, which allow to communicate freely with the people. Starting the school oral language is completely formed and the child pronounces correctly all sounds and is forming 
grammatically correct sentences, (Anspoka, 2008), although the child doesn't know grammatical laws.

Articulation disorders describe a child who has a problem with speech production. In general, articulation disorders are indicated when a child's speech at age of 3 years cannot be understood by adults (not members of the family). Often these disorders can be contributed to specific physical impairment such as cleft palate, cleft lip, tongue-tie or other.

Articulation disorder means that child mispronounces speech sounds by distorting, substituting, omitting or adding sounds and this makes child's speech difficult to understand. Articulation disorder is obvious when a child pronounces [th] instead of [s], [r] substitutes with [l] (thaule = saule; lati $=$ rati). Many articulation errors are developmental in nature, some sounds develop later and for example sound $[r]$ could be pronounced incorrectly until age of 5 . Sound becomes clear only when a child matures. Child should be evaluated and if speech and language pathologist consider, that therapy is not necessary, child should be monitored until articulation becomes clear or until child is ready for therapy.

One thing is when a child mispronounces sound in an easier way, but the other is when sound is substituted. Some mispronunciations are related to phonological processing disorders. Children with these disorders are at a very high risk for later learning disabilities (problems in reading and writing). If the cause of such disorders is of neurological origin, speech pathologists use such diagnosis as dysarthria or dyspraxia (Blakemore, Frith, 2005).

Then inability to create sounds and speech at the level expected at child's age is neurologically based and speech pathologists are working even before the age of three. The hearing of the child must be checked obligatory, because similar pronunciation mistakes can develop due to hearing impairment, but in such case the content of correctional developmental actions and principals will be different. When setting speech therapeutic conclusion about disorders of phonological system, it is necessary to consult with the doctors, in order to exclude existence of other developmental disabilities (anatomical disorders in the articulation apparatus and in the brains, intellectual disability, vision and hearing disorders and other abnormalities) (Tübele, 2002). Lack of speech sound acquisition could be caused by socio-psychological problems at home, in family or by other important aspects such as environmental deprivation. In the age of three there is a possibility that the conclusion can not be set precisely, but it is possible to make suggestions about the possible disorder, which can be observed in the dynamic and the amount of help and it's necessity can be set accordingly.

Phonological system is very important, when speaking about abilities to read and write. Phonological disorder occurs when ability to produce some or all sounds necessary for speech and normally used at child's age does not develop. There are different levels of severity of phonological disorder. These levels are stated 
depending on range from speech that is incomprehensible (even child's family members have difficulties to understand speech) to speech that is understandable for everybody, but there are mispronounced sounds.

If the child develops or already has speech and language development disorders, then the child can be faced with certain difficulties in many fields of life, especially starting the school education and by acquiring the reading and writing skills. (Tūbele, 2008).

Insufficient development of phonological system (phonemic perception) doesn't allow for the child to perceive the information precisely, to understand words and its meanings. In the Latvian language there are numbers of words, which differ with one phoneme, but it completely changes the meaning of the word (lapa - läpa, tēja - dēja etc.); there are such words also in English (pad - bad, trill - drill etc.). The difficulties will be not only during the learning process, but child's psychic development and social connections also can be negatively affected.

By studying children who attend preschool educational facilities younger group can be found deviations from the generally accepted norms of sound articulation, from phonetic regularities in the certain language. These deviations can be functional, which correspond to the child's concrete age; however exercises of articulation apparatus will allow to accelerate the sound pronunciation precision. Data from several studies testify, that approximately half of the children have speech and language development problems of different severity levels (Bakanova, 2010; Laganovska, 2011; Leimane, 2007). Speaking about the phonemic perception, in fact there is no time to wait, if it will develop or not? For stabilising of this process can be used different games and exercises and the childe would understand what are the differences between similar sounding and similar pronounceable sounds.

In certain extent it is already prophylactic action, which aim is in the school age to prevent the formation of writing and reading and consequently the learning disorders.

According to studies and theories of Vigotsky about the current and the nearest area it is important to realise that effective is such action which overtakes and promotes the development.

The current development area is the area in which the child is able to make actions independently, without help of adults, but the in the nearest development area the child is able to act only under the guidance of adults. Actions which are outside this area the child cannot perform (Выготский, 2003).

In the time, when the speech of child is not completely developed the specialist must be able to assess, what is formed and what is in the development process, what is starting to develop and important is, how it is happening. Speech that may be appropriate for a four-year-old child may be a sign of phonological disorder in a six-year-old. 
In order to evaluate and to analyse adequately the action of child's speech in each language there are studies about the development of child's speech in so called generally accepted age standard. In the Latvian language such studies are few, however little insight can be found in the studies of speech specialists and linguists (Markus, 2003; Miltina, 2008). Significant is that we could foresee the development of phonological deficit and try to prevent it by performing several prophylactic actions, which further the development of articulation apparatus, exercise voice and its correct use, develop finger muscles and turns the attention to the language and its regularities.

\section{Prevention}

Many scientists in the whole world have turned to the questions of prevention. The questions are raised also in the Standing Liaison Committee of Speech and Language Therapists in the European Union (CPLOL) professional practices, where to many European countries is offered to fill in questionnaires about the system of prevention in the countries and its legal regulation. It is not so, that in all countries the prevention activities in the speech therapy are subject to certain laws and regulatory documents. In fact it is the case just in few countries. The latest information is still being processed, because the previous study was performed in the year 1999 and certain changes took place (Definition of prevention).

With specific methods in many cases it is possible to prevent, delay or reduce appearance of different speech abnormalities. If in the years $1970^{\text {th }}, 1980^{\text {th }}$ the preventive speech therapy examination in the health clinics was regularity, now in many places this examination is not performed. The relevant section in the child's health record can be filled in also by paediatrician and sometimes it turns to formality, because the reality shows, that a child with entry that there is compliance with generally accepted norm of age, in age of five practically is not able to talk...

The association of Latvian speech therapists is repeatedly requested the Latvian Health Ministry to introduce compulsory preventive speech therapy examinations in the age of three and in the beginning of school. Till now there is no solution found to these questions!

The development of the speech in the ontogenesis is one of the most important questions, so that the specialist could evaluate in which moment we have to think about the exercises, help and support in the child's speech and language development process. Each stage in the development of the child is important, but for speech and language development significant are the sensitive periods in the development of the child. It should be spoken about the development of before speech, when the child develops voice using habits, babbling and first words, without which the child cannot start to speak in complete sentences. In which moment the child says his first word, is he using it consciously and how it is 
perceived by adults? Are we going to repeat and use child's nicknames and sound clusters or we nevertheless will give correct speech samples? What we will ask from child and of what he is able in one or another age? These questions should be discussed over and over again with parents and also with preschool teachers. The question of prevention is important and it is discussed among the specialists as well as the parents have their opinion.

The speech therapy speaks of primary, secondary and tertiary prevention: the main task of the primary prophylaxes is to prevent the formation of speech and language disturbances; the secondary prevention should delay the passing of the speech disturbance into the chronic form and to hinder the consequences of speech pathology; the aim of tertiary prophylaxes is social and work adaptation of persons with a speech pathology.

\section{Primary prevention}

Since the speech is psychic function, then primary prevention will be activities, which should be taken in the social, pedagogical and psychological fields. Basically the prophylactic measures should be taken even prior to child's birth. They would be healthy, adequate conditions for the mother as well as the genetic consultation. Already in this context is mentioned "risk factor" with which we understand different external environments conditions (biological as well as social), which can stimulate the formation of pathological conditions. Primary damage, which stimulates the formation of speech and language disturbances, may affect systems of hearing, vision, intellect and movement. The primary prevention is directed also to delay of formation of these disturbances and damages. If such disturbances have occurred, is necessary early intervention with main activities directed to development of orientating cognitive response, fixation of sight and movement of gaze, concentration of auditory attention, stimulation of movement activity, voice responses etc.

Big attention is turned to improvement of sensorial perception: visually, auditory, kinesthetic. With the compensation of damaged sensory functions the normalisation of speech development is stimulated (Волкова, 2006).

The socially - psychological risk factors and especially deprivation, which is described by Langmeier and Mateichek (Лангмейер, Матейчек, 1984), is the area, that requires special attention. Under deprivation is meant insufficient satisfaction of basic needs (emotional and sensory). In the performed studies is clearly indicated the connection between all kinds of deprivation and the development of the speech, which is hindered.

Psychologically traumatising situations develop not only in the family (excited, emotionally cold, impulsively or infantile parents, broken families or conflicts in it, inadequate or unbalanced education in the family), but also in the conflicts with 
adults and peers from the surrounding, which significantly affects development of language and stimulates the formation of several speech disturbances.

\section{Secondary prevention}

The consequences of any damage and disturbed development reflect in the psychic development of the child, often as first suffers the speech. The speech therapist should carry out wide explanatory work to the parents to be able to initiate as early as possible the correctional developmental actions, in order to be able as early as possible to put in motion the compensatory mechanisms. The earlier will be started even before speech correctional developmental actions, the less deviations will form in the development of child's speech and intellect. Sometimes in the families were children have speech disturbances, parents try to use gestures, so sort of making easier the communication, however the child has to hear the surrounding language to be able to accumulate the vocabulary, which will be necessary for the further development of the speech (Волкова, 2006). The bigger the child growth, he realizes more clearly, that he is different from others, that he is not able to speak fluently, clearly and understandably. Sometimes it makes child silent and speechless, because he doesn't want to be mocked, sometimes these are heavy experiences, because persons from surrounding annoy, make fun and mock. If it is done not only be peers but also by adults it may have hard consequences. Insufficient development of speech sound area and little developed phonemic processes hinder timely development of sound analyses and syntheses. In the further process the pupils will develop persistent learning difficulties, which like avalanche bring different problems in the learning process.

Important is mutual trust and understanding, which will allow to overcome certain difficulties, but in this process obligatory must be involved specialists teachers speech specialists, sometimes psychologists or doctors, who in complex action will reduce effects of disturbances.

\section{Tertiary prevention}

In separate cases of speech and language disturbances there is limited choice in possibilities to choose occupation and in the realization of own intentions. Help in case of severe speech and language disturbances has to be carried out complex in cooperation with teem of specialists and in such cases is important coordinated action, taking into consideration the individuality, wishes, interests, possibilities and real situation of each child. In the cases, when the necessity for help is obvious, arise questions about the best realisation of help, which specialists should be involved and how to insure the social possibilities, taking into consideration psycho physiological peculiarities, emotional state and to assess realistically the future options. 
Also these questions are not arranged properly, however in their necessity nobody has doubts. The tertiary prophylaxis is not the subject of this article and it will be not discussed in detail.

Important is the question about the previously mentioned primary prevention. Why should be worried, when nothing has happened yet? There is no need to be worried but it is necessary to evaluate the situation. Especially because the specialists are well aware of what happens, if the first signals, symptoms and signs of disturbances are not taken into consideration. Also the existing economical situation at the moment is unfavourable! In the preschool educational facilities mostly into focus of speech therapist comes child in age of five, because he is started to prepare for school. Then by playing games is acquired preschool educational programme, which provide a number of such skills that will be needed at school. Sometimes before the eyes (and ears) of speech therapist reveals unpleasant scene: child's speech is little understandable, the phonemic perception, which would secure successful acquisition of letters and mathematic perception is not developed. Where we have been earlier? The financing for the speech therapy action starting with age of three years has been found only in separate private facilities and development centres where also sometimes it is payable service.

In such circumstances much depends from professionalism, enthusiasm and being interested of speech therapist and preschool education teachers. In different studies (Mežule, 2010; Petrakova, 2009; Laksa, 2009) are offered the possibilities for preschool education teachers in cooperation with speech therapist to make more precise the pronunciation of sounds as well as to enrich and to clarify the vocabulary. The speech specialist is the person who identifies the children and makes so called "risk group", which is not included in the classes or occupied otherwise. Nonetheless these are children in development of which are to find some signals, to that should be turned bigger attention ahead of development in order to prevent the formation of speech defects. In this group should be included children which speech in the age of three is little understandable or it is practically not there (the child communicates with pointing gestures, sound complexes or separate words), children who often get ill (especially with tympanitis), the children with families in the social risk group (parents are alcoholics, low-income families, the families with reduced communication, parents are abroad for a long time etc.), children who's behaviour do not comply to the generally acceptable behavioural standards. The working together with all children the actions would be organised in such a way, that these children could have all opportunities to reach their peers and to complete those skills that were hindered due to several causes. There are many good and positive examples, were the speech therapists are able to interest preschool teachers by including into their everyday's practice necessary exercises of speech therapists for the activation of the speech apparatus. By carrying out these activities all together and making it without force, winners are all children 
because the exercise of the speech apparatus is helpful for all, but especially important it is for children, which we have included in so called risk group. If those children will not receive help in time, it is highly possible, that they will develop speech disturbances.

\section{Exercises}

Exercises are the way how to teach, how to develop some skills. In the speech therapy the correctional developmental actions the exercises are successfully used for the exercising of the articulation apparatus, also for exercising the muscles of hands as well as for development of phonemic perception and proper breathing (Волкова, 2006).

Exercises have to be used also for stimulation of mobility of articulation apparatus, by adjusting the voice volume and thinking about voice ergonomics, by adjusting the speech rhythm; parallel it has to be developed the finger musculature - their strength, range and accuracy.

Breathing exercises are, for example, "Games with the wind" (Александрова, 2005), they help to develop prolonged exfoliation by feeling on the skin of hand the direction and intensity of the air stream. It is possible to integrate those exercises in different classes in the preschool, blowing not only on the hand, but also by moving forward (or blowing into gates) colourful feathers, small cotton pads, it can be also colourful paper strips, which are hanged in the frame, they can be wind mills which turn, when the child blows enough strong and accurate. They can be also soup bubbles, which make great pleasure to the child, but at the same time it is correctional action for the development of proper air stream and prolonged exfoliation.

Especially significant are the exercises for the improvement of movements of lips and tongue, they improve the strength of movement, its range and accuracy (Miltina, 2005). The children starting already of age from 2 till three in the morning circle can send to each other air kisses and they can exercise the tongue in front of the mirror. It happens in the way of games and does not acquire much time and attention, but performing them regularly (at least one or several times a day) the result will be present. In the games can be included also several exercises for the development and improvement of phonemic perception, for example, to sing accurately the sounds - continuously, shorter, higher, lower; to beet rhythm with hands; to "conduct" - to show with hands the length of the sound, tempus; to imitate the song with music instruments etc. According to the age of the child it is possible to play also with different sounds and after also with the sounds of language. To distinguish differently sounding subjects, musical instruments; later to hear some certain word, syllable, sound. If for the two or three years old child are necessary exercises of the articulator apparatus, for the promotion of the of the mobility and accuracy of tongue and lips mobility, then the four years old child 
can already distinguish between sounds of language, to feel the rhythm of the language and to repeat the exercises, which are offered by parents, teachers.

In all ages the children have to exercise fingers, it helps to speak out precisely the sounds; also it improves the development of the language in general. To the finger games are devoted books, many studies of the students, all that has to be done is to use them and to implement into everyday's actions of the preschool teachers. Indispensable event are children's nursery rhymes that are meant not only for training of the memory but also for language feeling improvement and for promotion of phonemic perception. English scientists have performed studies about the influence of children's nursery rhymes to the later development of reading skills and have found significant correlation (Adams, 1995).

Depending of the age of child for the improvement of the phonemic perception can be used such methods as phonemic segmentation tasks, phoneme manipulation tasks, syllable-splitting tasks, blending tasks, oddity tasks and others (Adams, 1995).

Phonemic segmentation tasks mean that child must decompose a syllable into its component phonemes. If he can count to two or three, he can tap adequately two or three times according to the number of phonemes in this syllable. These actions are preceded by demonstration and training. In this case phonemes should be audibly distinguishable.

Phoneme manipulation tasks (mostly for $6-7$ year-old children) mean that children are given instructions to manipulate phonemes in words. Children are asked to pronounce a word after they have removed first, middle of last phoneme. If children are more skilled in phonemic segmentation, they can reorder phonemes in the syllable or add some extra phonemes (new words will be created and children will have a fun).

Syllable-splitting tasks mean that children are asked to break off the first phoneme of a word or syllable. This task is possible to perform even in 4-year-old children, only sometimes they can't understand what the word phoneme means, and children can perform the task, if we ask to break off the first letter... Later we can also explain to them, that phoneme could be heard, but letter is a written form of it. These tasks are easier than phoneme segmentation and phoneme manipulation tasks because it is always easier to know the first phoneme. It should be done in an attractive way, game which is natural way of acting in preschool children (Фомичева, 1989). Preschool teachers, speech and language pathologists working with $3-6$ year-old children are creative and will be able to find the best language which suits to our purpose - promote phonological awareness.

Blending tasks are similar to phonemic segmentation tasks, but they differ in at least two ways (Adams, 1995). In blending task phonemic segments are given to a child, and he has to know that these sounds can be put together into a word. If in a segmentation task stimulus is a single monosyllabic word, in a blending task 
the stimulus consists of between two and four subsyllabic utterances. It is also a question of remembering things, single, familiar, monosyllabic word is easier to memorize than a string of phonemes.

Oddity task means that child is presented with a set of three or four spoken words and is asked which of the words is different or does not belong. The decision has to be based on the first sound of the words, if they are more skilled, it can be the last (final) sound or even the middle one. Oddity tasks are one of the simplest and could be carried out at the age of three and four. Oddity tasks do not require the ability to decompose a syllable or word into a string of phonemes. They do not require the ability to fractionate a syllable. They require only that the children are able to compare and contrast similarities and differences in the sounds of syllables (Adams, 1995; Волкова, 2006; Сохин, 1979).

It is preferable that the exercises are taughd also to parents; in order to strengthen the acquired skills and that the children would have the possibility with parent's assistance to step on the successful road of development (Brooks, Goldstein, 2007). Only in the team work it is possible to achieve positive results and to succeed that the speech and language disorders don't develop at all or their formation is hindered. This will ensure good learning process at school, there will be less possibility for development of learning disturbances and in psychological and social area the child will be successful.

\section{Conclusions}

- It is necessary to follow up the development of the child's speech and language during a longer period of time, starting from the time before actual speech development, as early as from the age of three, when it is possible to foresee the potential deviations and start performing appropriate exercises.

- Specialists must have the knowledge about the regularities of speech and language formation during ontogenesis, in order to be able to assess the process of individual development and peculiarities of each child.

- In the speech therapy three levels of prophylaxis are distinguished:the primary, secondary and tertiary prophylaxis, each having its own aims and tasks.

- The primary prophylaxis foresees a complex of measures that are intended to minimize the development of speech and language disturbances, to reduce the risk of illnesses, which result in speech and language disorders.

- For children of approximately the age of three different exercises are recommended: those that would strengthen their general health and special exercises that would promote the mobility and precision of the muscles of the articulatory apparatus (the lips and the tongue), as well as breathing exercises and those that can develop the finger muscle movement amplitude, strength and accuracy. Children of the mentioned age group need to develop also their phonemic perception. 
- Exercises should be performed in cooperation with a speech therapist, preschool teachers, adults, and the child himself/herself should be actively involved in the process.

\section{References}

1. Adams, M. J. (1995) Beginning to Read: Thinking and Learning About Print. Massachusetts: A Bradford Book, 494 pp.

2. Anspoka, Z. (2008) Latviešu valodas didaktika. 1. - 4. klase. [Didactics of Latvian Language. 1st-4th class]. Riga: RaKa, 474 Ipp. (in Latvian).

3. Bakanova, O. (2010) Skannu izrunas traucējumu profilakse vidèjä pirmsskolas vecuma bērniem: Diplomdarbs. [Sound pronunciation disorder prevention on middle and preschool age children: Diploma]. Rīga: Latvijas Universitāte, 108 lpp. (in Latvian).

4. Blakemore, S.-J., Frith, U. (2005) The Learning Brain: Lessons for Education. United Kingdom: Blackwell Publishing, 216 pp.

5. Brooks, R., Goldstein, S. (2007) Das Resilienz-Buch: Wie Eltern ihre Kinder fürs Leben Stärken. Stuttgart: Klett-Cota, 376 S.

6. Definition of Prevention [skatits 09.06.2011], pieejams: http://www.cplol.eu/eng/ public/public_info.htm\#defin

7. Laganovska, E. (2011) Drāmas elementu izmantošana fonemātiskās uztveres traucējumu mazināšanā 5 - 6 gadígiem bèrniem: Maǵistra darbs. [Usage of drama elements in phonematic perceptual distortions to 5-6 year old childrens: Master's work]. Rīga: Latvijas Unversitāte, 81 lpp. (in Latvian).

8. Leimane, J. (2007) Säkotnējā vārdu kräjuma veidošana bērniem ar valodas sistēmas nepietiekamu attīstību trešajā dzîves gadā: Diplomdarbs. [Building the initial vocabulary for children with underdevelopment of language-development system in the third year of life: Diploma]. Rīga: Latvijas Universitāte, 47 lpp. (in Latvian).

9. L̦aksa, A. (2009) Didaktiskā materiāla izmantošana vārdu kräjuma aktivizēšanai jaunākā pirmsskolas vecuma bērniem: Maǵistra darbs. [Usage of didactics material to activate preschool age children vocabulary: Masters Thesis]. Rīga: Latvijas Universitāte, 80 lpp. (in Latvian).

10. Markus, D. (2003) Bērna valoda: no pirmā kliedziena lìdz pasakai. [Children language from first scream till the fairytale]. Rīga: Rasa ABC, 143 lpp. (in Latvian).

11. Mežule, A. (2010) Pirmsskolas skolotāja darbïba vārdu kräjuma paplašināšanā 4 - 5 gadus veciem bērniem: Maǵistra darbs. [Preschool teacher's action to expand 4-5 years age children vocabulary: Master Thesis]. Rĩga: Latvijas Universitāte, 98 lpp. (in Latvian).

12. Petrakova, T. (2009) Pirmsskolas skolotāja darbïba runas traucējumu mazināšanā pirmsskolas vecuma bèrniem 3 - 5 gadu vecumā: Maǵistra darbs. [Preschool teacher speech disorder reduction activities for preschool children 3 - 5 year olds: Master's work]. Rīga: Latvijas Universitāte, 88 Ipp. (in Latvian). 
13. Miltina, I. (2005) Skaņu izrunas traucējumi. [Disorder of sound pronunciation]. Rīga: RaKa, 251 lpp. (in Latvian).

14. Miltina, I. (2008) Skolotāja logopèda darba mape. [Teacher's speech therapist working folder]. Rīga: RaKa, 302 lpp. (in Latvian).

15. Rüķe-Dravin,a, V. (1992) No 5 mènešiem lìdz 5 gadiem. [From 5 months to 5 years]. Rìga: Zvaigzne, 415 lpp. (in Latvian).

16. Tūbele, S. (2008) Disleksija vai lasišanas traucējumi. [Dyslexia or reading disorder]. Rīga: RaKa, 161 lpp. (in Latvian).

17. Tūbele, S. (2002) Skolēna runas attīstïbas vērtēšana. [The assessement of student's speech development]. Rīga: RaKa, 165 lpp. (in Latvian).

18. Александрова, Т. (2005) Живые звуки или Фонетика для дошкольников. [Live sounds or phonetics for preschoolers]. Санкт-Петербург: Детство-пресс, 48 с. (in Russian).

19. Волкова, Л. С. (2006) Логопедия. Москва: Владос, 704 с. (in Russian).

20. Выготский, Л. С. (2003) Основы дефектологии. [Fundamentals of defectology.]. Санкт-Петербург: Лань, 656 с. (in Russian).

21. Лангмейер, И., Матейчек, 3. (1984) Психическая депривация в детском возрасте. [Psychological deprivation in childhood]. Прага: Авиценнум, Медицинское издательство, 334 c. (in Russian).

22. Сохин, В. (ред.) (1979) Развитие речи детей дошкольного возраста. [Speech development of preschool children]. Москва: Просвещение, 223 c. (in Russian).

23. Фомичева, М. (1989) Воспитание у детей правильного звукопроизношения: Практикум по логопедии. [Educating the children correct sound pronunciation: Workshop on speech therapy]. Москва: Просвещение, 239 с. (in Russian).

\section{Asoc. prof., Dr. paed. Sarmīte Tübele}

Riga Teacher Training and Educational Management Academy,

Address: Imantas 7. līnija 1, Riga, LV-1083, Latvia;

University of Latvia, Faculty of Education, Psychology and Art, Address: Jurmalas Gatve 74/76, Riga, LV-1083, Latvia;

Phone: +37126438441

e-mail: sarmite.tubele@lu.lv; tubele@gmail.com 